Tạp chí Các Khoa học về Trái Đất, 38 (1), 59-65

\begin{tabular}{c} 
Viện Hàn lâm Khoa học và Công nghệ Việt Nam \\
Tạp chí Các Khoa học về Trái Đất \\
(VAST) \\
Website: http://www.vjs.ac.vn/index.php/jse \\
\hline
\end{tabular}

\title{
Đặc điểm địa mạo động lực vùng cửa sông ven biển Sông Mã, tỉnh Thanh Hóa
}

\author{
Nguyễn Công Quân*, Phạm Văn Hùng \\ Viện Địa chất, Viện Hàn lâm Khoa học và Công nghệ Việt Nam
}

Chấp nhận đăng: 15 - 3 - 2016

\section{ABSTRACT}

\section{Characteristics of dynamic geomorphology of coastal-river mouth zones of Ma river, Thanh Hoa province}

Study of dynamic geomorphological characteristics of coastal-river mouth zones of Song Ma in Thanh Hoa Province has an important meaning for rationally natural resource exploitation and use for local sustainably socio-economic development. Main factors affecting recent dynamic processes in the coastal-river mouth zones of Song Ma include river flows, nearshore currents and active tectonic movements of the crust; controlling the formation and development of modern topography of the coastal-river mouth zones. Sedimentation process forms banks, bars, mounds, dunes and Holocene-Recent plains at the region of Len and Hoi river mouths. Especially, high accumulation rate at Len river mouth forms larger plains, banks, bars, mounds having seaward aggradational rate about 40-50 m/yr; while at Hoi river mouth, because of low flow carrying lesser source material, weaker deposition, the cumulation rate along the northern and southern coast of Hoi river mouth reaches 5 to $10 \mathrm{~m} /$ year. Strong erosional processes are developed at nearshore regions having less dense sediment, small river mouths or no river mouth, or occurence of active faults, such as Lach Truong mouth and in the bank of Hoi river mouth. Maximum erosion in Cửa Lach Truong is about 5 to 6 $\mathrm{m} / \mathrm{year}$; while at Cua Hoi the erosion is weaker, only about 3-5 m/year.

(C)2016 Vietnam Academy of Science and Technology

\section{Mở đầu}

Địa mạo động lực vùng cửa sông ven biển (VCSVB) nghiên cứu các quá trình hình thành và phát triển của địa hình hiện đại ở VCSVB dưới tác động của các yếu tố ngoại sinh, nội sinh và nhân sinh. Trong đó, yếu tố ngoại sinh là chủ yếu, mà cụ thể là sự tương tác giữa yếu tố sông và biển. Do đó, nghiên cứu địa mạo động lực VCSVB giúp chúng ta hiểu rõ hơn quy luật hình thành, lịch sử phát triển của dải địa hình hiện đại VCSVB, các quá trình động lực hiện đại diễn ra, từ đó xây dựng cơ sở khoa học cho quy hoạch khai thác và sử dụng hợp lý tài nguyên lãnh thổ phục vụ phát triển

*Tác giả liên hệ, Email: nguyen congquan_igs@yahoo.com bền vững $\mathrm{KT}-\mathrm{XH}$ và bảo vệ môi trường (Nguyễn Văn Cư và nnk, 1999).

VCSVB sông Mã, tỉnh Thanh Hóa là sản phẩm của các quá trình tương tác sông-biển và chịu ảnh hưởng sâu sắc hoạt động của con người. Sự hình thành và phát triển của VCSVB chịu sự chi phối mạnh mẽ bởi các quá trình địa mạo động lực của sông và biển ven bờ. Sự tương tác giữa sông và biển đã tạo ra hệ cân bằng động tự nhiên ở VCSVB, mà sự tồn tại của các đồng bằng, bãi triều, các cồn cát, bar, gò nổi cao và các quá trình bồi lấp, xói lở là bức tranh chung phản ánh quá trình cân bằng động nói trên. Chuyển động kiến tạo hiện đại, đặc biệt là hoạt động đứt gãy đã góp phần thúc đẩy các quá trình địa mạo động lực phát triển. Cùng với nhịp độ phát triển $\mathrm{KT}-\mathrm{XH}$, các 


\section{N.C. Quân và P.V. Hùng/Tạp chí Các Khoa học về Trái Đất, Tập 38 (2016)}

hoạt động của con người, như: di dân tự do, chặt phá rừng phòng hộ đầu nguồn, xây dựng các hồ điều tiết nước vùng thượng lưu, đào đắp các đầm, hồ, ao nuôi trồng thủy, hải sản cũng ảnh hưởng sâu sắc đến sự biến động của VCSVB và lân cận. Xuất phát từ nhu cầu thực tiễn khách quan, công trình này bước đầu làm sáng tỏ đặc điểm địa mạo động lực VCSVB sông Mã, tỉnh Thanh Hóa, xác lập quy luật hình thành và phát triển địa hình hiện đại, làm cơ sở cho phân vùng quy hoạch phát triển bền vững $\mathrm{KT}-\mathrm{XH}$ ở địa phương.

Các phương pháp nghiên cứu đã được ứng dụng nghiên cứu địa mạo động lực VCSVB bao gồm: phương pháp phân tích ảnh viễn thám và bản đồ, khảo sát thực địa, phân tích trắc lượng hình thái địa hình, biến dạng địa mạo, trầm tích trẻ và phân tích tổng hợp. Công trình này sử dụng các tư liệu viễn thám bao gồm: Landsat-7, Landsat-8, SPOT-5 có độ phân giải $15-30 \mathrm{~m}$, ảnh máy bay 1952, 1978; bản đồ địa hình tỷ lệ 1:50.000 các năm 1965, 2002, 2010. Kết quả phân tích ảnh viễn thám và bản đồ kết hợp khảo sát thực địa, phân tích tổng hợp các tài liệu địa chất trầm tích trẻ và phân tích các biến dạng địa mạo cho phép xác định đặc điểm địa mạo động lực (các quá trình xói lở, bồi tụ) ở VCSVB sông Mã, tỉnh Thanh Hóa.

\section{2. Đặc điểm địa mạo động lực vùng cửa sông ven biển sông Mã}

Hệ thống sông Mã bắt nguồn từ Điện Biên, chảy qua lãnh thổ Lào vào Việt Nam trên địa phận tỉnh Thanh Hóa, gồm 90 con sông nhánh (phụ lưu) hợp thành. Vùng hạ lưu sông Mã thuộc tỉnh Thanh Hóa có các phụ lưu: sông Bưởi và sông Chu. Sông Bưởi bắt nguồn từ núi $\mathrm{Chu}$, Hòa Bình nhập vào sông Mã tại Vĩnh Khang. Sông Chu bắt nguồn từ lãnh thổ Lào đổ vào sông Mã tại Giàng. Sông Mã đổ ra biển ở các Cửa Hới, Lạch Trường và Lèn. Năm 1920, trên sông Chu người Pháp đã xây dựng đập dâng Bái Thượng nhằm dẫn nước tưới cho vùng phía nam sông, tạo nên hệ thống Thủy nông nam sông Chu. Ngày nay, trên hệ thống sông Mã, phát triển nhiều hồ thủy điện, thủy lợi, nâng cấp và cải tạo năng lực tưới và thoát lũ cho toàn bộ đồng bằng Thanh Hóa. Quá trình hình thành và phát triển hệ thống sông Mã gắn liền với hình thành đồng bằng Thanh Hóa. VCSVB sông Mã được hình thành trong bối cảnh chung đó, dưới tác động của cả sông và biển. Các quá trình địa mạo động lực (xói lở, bồi tụ) ở đây phản ánh mối tác động tương hỗ của các quá trình nội sinh (chuyển động hiện đại, đứt gãy hoạt động), ngoại sinh (thủy thạch động lực sông, biển) và hoạt động kinh tế dân sinh.

\subsection{Các yếu tố tác động đến quá trình xói lở và bồi tụ}

\subsubsection{Chế độ dòng chảy của sông}

Chế độ dòng chảy của sông là yếu tố quan trọng, trực tiếp tác động đến VCSVB trong quá trình diễn ra xói lở và bồi tụ. Đây là vùng hạ lưu của hệ thống sông Mã, hàng năm trung bình đưa ra biển hàng triệu (khoảng 5,17 triệu) tấn phù sa (Nguyễn Văn Cư và nnk, 1999; Nguyễn Văn Cư và Phạm Huy Tiến, 2003). Toàn bộ lượng phù sa trên đổ ra biển qua các cửa Hới, Lạch Trường và Lèn. Ngoài ra, còn nhiều sông ngòi nội đồng tạo nên ở đây một mạng lưới dày đặc, chằng chịt. Chính điều này đã làm cho chế độ động lực VCSVB diễn ra rất phức tạp và sự phức tạp này ngày càng được gia tăng trong những thập kỷ gần đây do tác động tích cực hoạt động của con người. Dòng chảy cát bùn là nguồn vật liệu chủ yếu thành tạo nên địa hình hiện đại VCSVB sông Mã. Sông mã có lượng bùn cát lớn, đặc biệt vào mùa mưa lũ, lượng bùn cát được tích tụ lại ở VCSVB.

\subsubsection{Chế độ dòng chảy và sóng ven bò̀}

Chế độ dòng chảy ven bờ đóng vai trò quan trọng trong hình thành và phát triển địa hình hiện đại VCSVB sông Mã. Ở vùng biển nông ngoài đới sóng vỡ đến độ sâu $20 \mathrm{~m}$, dòng triều có phương đông bắc-tây nam. Tính chất nhật triều không đều biểu hiện rõ. Đó là vùng có địa hình phức tạp, sóng triều bị biến dạng và năng lượng phân tán thành các sóng nước nông. Thủy triều ở VCSVB sông Mã thuộc chế độ nhật triều không đều với chu kỳ 24 giờ trong ngày. Trong một kỳ triều, còn có ngày xuất hiện bán nhật triều. Thời gian triều lên ngắn 7 - 8 giờ, những ngày triều cường thời gian triều lên $8-9$ giờ, thời gian triều rút $15-16$ giờ trong ngày. Trong một tháng có 2 lần triều cường, 2 lần triều kém; nhưng có khi có 3 lần triều cường, 2 lần triều 
Tạp chí Các Khoa học về Trái Đất, 38 (1), 59-65

kém, hoặc 2 lần triều cường, 3 lần triều kém. Mực nước lớn nhất và biên độ triều lớn nhất cao nhất ở cửa sông và càng về thượng lưu càng giảm. Biên độ lớn nhất của mực triều đạt $3,19 \mathrm{~m}$ ở Cửa Hới (xã Hoàng Tân) và $2,58 \mathrm{~m}$ ở Cửa Lạch Trường (tại Lạch Sung) (Nguyễn Văn Cư và Phạm Huy Tiến, 2003; Phạm Huy Tiến và nnk, 2004). Dòng triều không những có khả năng đưa các hạt trầm tích lơ lửng đi xa, mà còn có khả năng bào mòn các bar, val cát ngầm, sườn bờ ngầm.

Dòng sóng ven bờ hình thành trong đới sóng vỡ, năng lượng sóng khi vỡ đã tạo ra dòng chảy. Trên thực tế dòng chảy sóng xuất hiện gián đoạn và không liên tục giữa các chu kỳ sóng vỡ. VCSVB sông Mã, tỉnh Thanh Hóa có địa hình khá bằng phẳng, song lại bị chia cắt nhiều bởi đê biển và các bar, cồn cát trước cửa sông. Phía ngoài cùng là sườn bờ ngầm thường xuyên ngập nước, giữa là các bãi triều rộng, phẳng và trong cùng là các cồn cát nổi cao và các đê biển. Khi triều lên từ chân triều thấp đến đỉnh triều cao đã tạo ra đới sóng vỡ. Tại sườn bờ ngầm, ven các chân đê và sườn bờ các cồn cát do độ dốc lớn, sóng bị phá hủy trong dải hẹp. Đoạn bờ phía bắc và nam cửa Lạch Trường với đường bờ biển thẳng, hơn nữa cách xa các cửa sông lớn, thiếu nguồn bồi tích, lại đón hầu hết các hướng sóng tác động mạnh trong mùa đông và mùa hè, nên đoạn bờ này hiện đang trong tình trạng xói lở nghiêm trọng.

Dòng chảy trôi do gió thuộc loại dòng chảy ổn định, phụ thuộc chủ yếu vào tốc độ gió, hướng gió và thời gian tồn tại của hướng gió. Ngoài ra, dòng chảy trôi do gió còn bị ảnh hưởng rất lớn của địa hình, ở mỗi khu vực khác nhau trị số tốc độ cũng khác nhau. Đoạn bờ sông Mã là vùng biển hàng năm chịu tác động mạnh của gió mùa Đông Bắc, gió mùa Đông Nam và cũng thường xuyên chịu tác động của bão, nên dòng trôi do gió ở đây tương đối phát triển. Mùa đông, vận tốc dòng trôi do gió lớn đã ảnh hưởng đến sự phát triển của các cồn ở Cửa Lèn và Cửa Hới.

\subsubsection{Tác động hồn hợp của sông và biển}

Ở VCSVB, kết quả của sự tương tác giữa dòng triều và dòng sông hình thành dòng chảy tổng hợp. Ở khu vực ven bờ ngoài, dòng tổng hợp là kết quả tương tác của hầu hết các dòng thành phần, trong đó chủ yếu là dòng sông, dòng triều và dòng sóng dọc bờ. Sự tương tác giữa chúng, hoặc triệt tiêu dần hoặc cộng hưởng tốc độ làm cho cả hướng và trị số tốc độ luôn biến đổi phụ thuộc vào chu kỳ dao động mực nước ngày đêm của thủy triều, của mùa gió tác động và chế độ thủy văn của sông Mã. Ở phía đông Cửa Lạch Trường, sự tương tác giữa dòng triều và dòng sóng diễn ra khá mạnh do ở đây cả 2 thành phần này đều có động năng lớn (Nguyễn Văn Cư và Phạm Huy Tiến, 2003).

VCSVB sông Mã là vùng biển thoáng, bãi triều nông và trải rộng. Nguồn bùn cát chính cung cấp cho vùng cửa sông là từ sông ngòi đưa ra và phần lớn được vận chuyển vào mùa lũ ở các trạng thái lơ lửng, di đẩy và bán di đẩy. Những cỡ hạt nhỏ, mịn được đưa ra xa bờ hoặc lắng đọng trong vùng khuất sóng (trong các bãi sú vẹt). Ngược lại, các cỡ hạt thô có khả năng lắng đọng lại ở những vùng có điều kiện động lực mạnh hơn, nhất là các vùng nước chảy quẩn, phát triển thành các bãi cát ngầm.

\subsubsection{Xây dựng các công trình đê, hồ chứa}

Hệ thống đê sông và đê biển đã được hình thành từ lâu đời và ngày càng được tu bổ ổn định. Đây là hệ thống công trình để phòng chống lũ, lụt cho vùng đồng bằng và ven biển, đảm bảo sự bình yên cho hàng triệu người trong mùa mưa, bão lũ. Vấn đề này đã được đề cập ở nhiều công trình khoa học (Nguyễn Văn Cư và Phạm Huy Tiến, 2003, Phạm Văn Hùng và Vũ Thị Thu Hoài, 2009; Hoàng Ngọc Quang và nnk, 2008). Hệ thống đê biển, ngoài việc ngăn các loại sóng biển, thủy triều, nước dâng do bão và ngăn mặn, còn tạo điều kiện để khai hoang phát triển vùng đồng bằng ven biển. Phù sa sông hàng năm bồi đắp cho đồng bằng ngày càng được mở rộng; tốc độ bồi đắp từ cửa sông tiến ra biển ở Cửa Lèn trung bình là 30-40 m/năm, Cửa Hới khoảng 10m/năm. Hệ thống đê đã triệt tiêu khả năng lắng đọng phù sa ở các đồng trũng dọc sông và các bãi triều cao (hình 1,2 ).

Tương tự như trên hệ thống sông Hồng ở VCSVB đồng bằng Bắc Bộ (Phạm Quang Sơn và nnk, 2007), việc xây dựng hệ thống các hồ thủy điện, thủy lợi ở vùng thượng lưu và trung lưu của hệ thống sông Mã đã ảnh hưởng trực tiếp đến các quá trình địa mạo động lực ở VCSVB. Các hồ Cửa Đạt, Đồng Ngư, Đồng Múc, Bỉnh Công, Quặng, Hồ Me, Hồ Vưng, Hồ Bung đi vào hoạt động đã làm chế độ dòng chảy cũng như nguồn bồi tích ở hạ lưu sông Mã có sự thay đổi. Trong điều kiện lượng bồi tích đã tích đọng trong các hồ chứa, quá trình xói lở VCSVB có điều kiện phát triển. 
N.C. Quân và P.V. Hùng/Tạp chí Các Khoa học về Trái Đất, Tập 38 (2016)

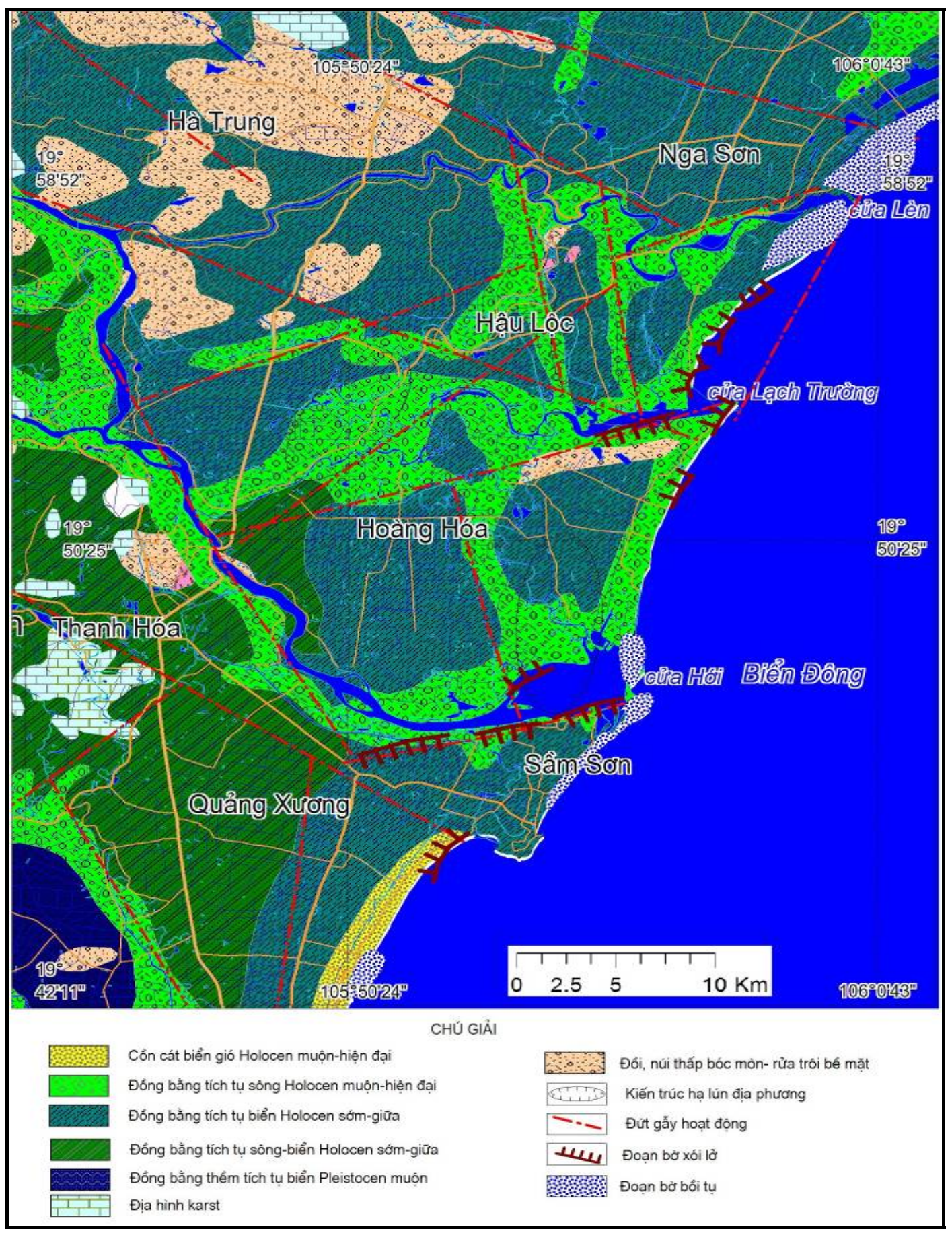

Hình 1. Bản đồ địa mạo vùng cửa sông ven biển sông Mã, tỉnh Thanh Hóa 
Tạp chí Các Khoa học về Trái Đất, 38 (1), 59-65

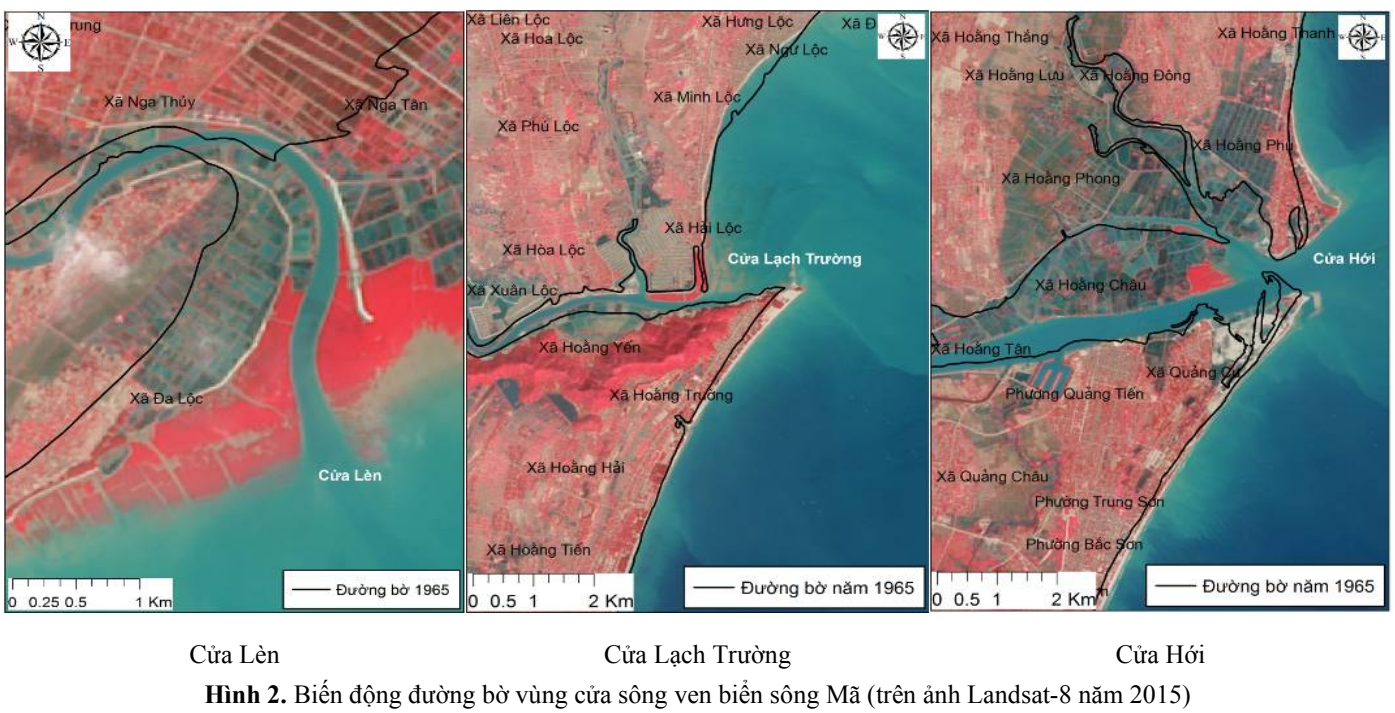

\subsubsection{Hoạt động kiến tạo hiện đại}

VCSVB sông Mã nằm trong vùng tiếp giáp giữa hai miền kiến tạo lớn mà ranh giới giữa chúng là đứt gãy Sông Mã, phía đông bắc là miền kiến trúc nâng Tây Bắc Bộ với các kiến trúc dạng tuyến, khối tảng đan xen nhau, phía tây nam thuộc miền kiến trúc Bắc Trung Bộ có kiến trúc dạng vòm khối tảng, khối tảng phân dị. Trên bình đồ kiến trúc VCSVB sông Mã phân bố khối Quảng Xương, Hoằng Hóa và Hậu Lộc-Nga Sơn. Khối Quảng Xương có dạng đẳng thước, phía đông bắc tiếp giáp với khối Hoằng Hóa qua đứt gãy Thiệu Hóa-Sầm Sơn (nhánh của đới đứt gãy Sông Mã). Trong Tân kiến tạo, khối này chuyển động hạ lún yếu với biên độ $100-150 \mathrm{~m}$, càng về phía đông biên độ hạ lún càng lớn. Khối Hoằng Hóa có dạng đẳng thước, phía đông bắc tiếp giáp với khối Hậu Lộc qua đứt gãy Vĩnh Lộc-Lạch Trường. Trong Tân kiến tạo, khối này chuyển động hạ lún yếu với biên độ 50-100m. Khối Hậu Lộc-Nga Sơn nằm ở phía bắc VCSVB. Trong Tân kiến tạo khối này chuyển động hạ lún yếu với biên độ $50 \mathrm{~m}$. Trong khu vực nghiên cứu phân bố hai đứt gãy sâu Sơn La-Bỉm Sơn và Sông Mã. Các đứt gãy bậc cao phân bố rải rác trong khu vực nghiên cứu có phương TB-ĐN, ĐB-TN, á kinh tuyển và á vỹ tuyến. Hoạt động hiện đại của chúng thể hiện rõ nét trên địa hình, trên ảnh vệ tinh, các biến dạng địa chất, dị thường địa hóa, địa nhiệt, xuất lộ nước nóng và những điểm nứt đất và trận động đất (Nguyễn Văn Hùng, 2002).
Như vậy, chuyển động tân kiến tạo và kiến tạo hiện đại diễn ra khá mạnh mẽ ở VCSVB sông Mã. Chuyển động nâng lển, hạ xuống phân dị theo phương $\mathrm{DB}-\mathrm{TN}$ và $\mathrm{TB}-\mathrm{DN}$, đồng thời với những hoạt động tích cực của các đứt gãy đã góp phần quan trọng trong hình thành địa hình VCSVB, thúc đẩy các quá trình xói lở và bồi tụ phát triển. Vai trò của yếu tố kiến tạo trong phát sinh xói lở, bồi tụ ở VCSVB đã được đề cập đến trong công trình của Nguyễn Thế Thôn (1994). Chuyển động hạ lún hiện đại vỏ Trái đất trong điều kiện thiếu hụt trầm tích, biển lấn sâu vào đất liền, gây nên hiện tượng xói lở bờ biển, như đã và đang diễn ra ở dải ven bờ Hoằng Hóa, Hậu Lộc, Quảng Xương và Tĩnh Gia. Tại Nga Sơn, chuyển động hạ lún điều hoà diễn ra trong điều kiện lượng bồi tích cung cấp rất lớn, tốc độ lắng đọng trầm tích lớn, làm cho lục địa ngày càng mở rộng hơn về phía biển. Hoạt động tích cực của các đứt gãy Sông Mã, Sơn La-Bỉm Sơn và một số đứt gãy phương TB-ĐN, ĐB-TN và á kinh tuyến cùng với chuyển động hạ lún ở cánh hạ của các đứt gãy là một trong những yếu tố tác động trực tiếp đến xói lở VCSVB ở đây. Chính sự hoạt động của đứt gãy đã phá hủy đất đá, tạo những đoạn đường bờ có cấu tạo bởi vật liệu bở rời rất dễ dàng bị sóng, dòng chảy ven bờ cuốn trôi mang đi nơi khác. Do vậy, hầu hết các điểm xói lở bờ biển phân bố dọc đứt gãy chạy dọc bờ sông, bờ biển, hoặc ở những nơi đứt gãy cắt ra bờ biển, đặc biệt ở những nút giao của các đứt gãy như ở Hậu Lộc, Hoằng Hóa, Quảng Xương và Tĩnh Gia. 


\section{N.C. Quân và P.V. Hùng/Tạp chí Các Khoa học về Trái Đất, Tập 38 (2016)}

\section{2. Đặc điểm địa mạo động lực}

Các quá trình địa mạo động lực, mà chủ yếu là các quá trình bồi tụ và xói lở, đã hình thành, phát triển dải địa hình hiện đại VCSVB sông Mã và lân cận rất đa dạng, có những đặc trưng riêng (bảng 1 , hình 1).

Bảng 1. Bảng tổng hợp mức độ xói lở, bồi tụ vùng cửa sông ven biển sông Mã

\begin{tabular}{|c|c|c|c|}
\hline Huyện & Xã & $\begin{array}{c}\text { Tốc độ bồi tụ } \\
\text { 1965-2015 } \\
\text { (m/năm) }\end{array}$ & $\begin{array}{c}\text { Tốc độ xói lở } \\
\text { 1965-2015 } \\
\text { (m/năm) } \\
\end{array}$ \\
\hline \multirow[t]{3}{*}{ Nga Sơn } & Nga Tiến & 60 & \\
\hline & Nga Tân & 40 & \\
\hline & Nga Thủy & 45 & \\
\hline \multirow[t]{6}{*}{ Hậu Lộc } & Đại Lộc & 12 & \\
\hline & Hưng Lộc & 3 & \\
\hline & Ngư Lộc & & 4 \\
\hline & Minh Lộc & & 6 \\
\hline & Hải Lộc & 4,5 & \\
\hline & Đại Lộc & 12 & \\
\hline \multirow[t]{9}{*}{ Hoăng Hoá } & Hoăng Lộc & 3 & \\
\hline & Hoằng Yến & 4,5 & \\
\hline & Hoằng Trường & 6 & \\
\hline & Hoằng Tiến & & 3 \\
\hline & Hoằng Thanh & & 3 \\
\hline & Hoằng Phụ & 12 & \\
\hline & Hoằng Lộc & 3 & \\
\hline & Hoằng Yến & 4,5 & \\
\hline & Hoằng Trường & 6. & \\
\hline \multirow[t]{4}{*}{ Sầm Sơn } & Quảng Cư & & 5 \\
\hline & Trung Sơn & 5 & \\
\hline & Bắc Sơn & 4 & \\
\hline & Trường_Sơn & 4 & \\
\hline \multirow[t]{9}{*}{ Quảng Xương } & Quảng Phú & & 4 \\
\hline & Quảng Châu & & 4 \\
\hline & Quảng Đại & & 3 \\
\hline & Quảng Hải & & 3 \\
\hline & Quảng Thái & & 3 \\
\hline & Quảng Lợi & & 3 \\
\hline & Quảng Phú & & 4 \\
\hline & Quảng Châu & & 4 \\
\hline & Quảng Đại & & 3 \\
\hline
\end{tabular}

\subsubsection{Quá trình bồi tụ}

VCSVB sông Mã hình thành và phát triển dưới tác động của các yếu tố nội, ngoại và nhân sinh. Trong đó quá trình tương tác sông-biển cùng với chuyển động hiện đại vỏ Trái đất đóng vai trò quan trọng hơn cả trong hình thành đồng bằng tích tụ VCSVB sông Mã. Quá trình tích tụ các trầm tích sông, sông - biển, biển diễn ra chủ yếu trong thời kỳ Holocen. Phần phía nam của VCSVB, dưới tác động hỗn hợp sông-biển đã tích tụ các trầm tích có nguồn gốc sông-biển hỗn hợp; trong khi phần phía đông bắc của vùng này lại chủ yếu tích tụ các trầm tích biển (hình 1).

Địa hình đồng bằng VCSVB sông Mã đã được hình thành trong thời kỳ Holocen sớm -giữa. Đến thời kỳ Holocen muộn (biển thoái), quá trình tích tụ chủ yếu dọc theo sông Mã và các chi lưu của nó. Địa hình tích tụ chủ yêu có nguồn gốc sông (các bãi bồi và thềm 1). Hiện nay, tại một số cửa sông, tồn tại cửa sông lồi bồi tụ lấn biển, như cửa Lèn và cửa Hới. Chúng biến động rất phức tạp, không ổn định trong điều kiện chuyển động nâng lên, hạ xuống cục bộ và lượng bồi tích dư thừa hoặc thiếu hụt. Ở cửa Lèn phân bố vùng đất bồi dài hàng chục kilomet, rộng $1,5-2,0 \mathrm{~km}$. Cửa Lèn được bồi tụ và phát triển nhanh về phía biển với hàng loạt các cồn nổi cao. Tốc độ phát triển các bãi, cồn, bar diễn ra không đồng đều ở hai phía cửa sông; tốc độ bồi tụ về phía biển trung bình 40-50m/năm. Tại cửa Hới, quá trình bồi tụ diễn ra yếu hơn nhiều so với cửa Lèn. Tốc độ bồi tụ về phía biển đạt $5-10 \mathrm{~m} /$ năm (bảng 1, hình 2). Điểm khác biệt cơ bản so với Cửa Lèn là Cửa Hới phát triển bãi trong cửa sông, nhờ có nguồn bồi tích không lớn từ sông Mã đưa ra và bồi tụ theo kiểu lấp góc vùng bờ lõm. Vùng cửa Lèn phát triển nhanh còn nhờ vị trí thuận lợi nằm trong góc vịnh nước nông nửa khép kín. Cửa sông tránh được tác động mạnh của các hướng sóng chính ở ven bờ Bắc Bộ, ít chịu tác động của hướng sóng đông bắc. Các hướng sóng nam, đông nam có tác động không mạnh do hiện tượng sóng phân kỳ ở vùng nước nông có đường bờ lõm.

Quá trình thành tạo và phát triển các đồng bằng, bãi, bar, cồn hiện đại ở VCSVB sông Mã là kết quả tương tác của các yếu tố tự nhiên và con người trên phạm vi rộng từ thượng nguồn các con sông đến vùng cửa sông và ven bờ biển. Nguồn vật liệu do sông ngòi cung cấp phần lớn được vận chuyển ra vào mùa lũ và tích tụ lại ở VCSVB sông Mã. Trong đồng bằng, bề dày trầm tích Đệ tứ tăng lên rõ rệt theo hướng ra phía biển với các thành phần chủ yếu là cuội, sỏi, sạn, cát, sét (Nguyễn Ngọc Quang và nnk, 2008). Quá trình tích tụ xảy ra mạnh mẽ nhất ở khu vực Cửa Hới, Lạch Trường và Cửa Lèn; chúng hình thành và phát triển các cồn dọc cửa sông, các val, bar dọc bờ biển.

\subsubsection{Quá trình xói lở}

Quá trình xói lở diễn ra khá phức tạp trên VCSVB sông Mã. Tại Quảng Xương, Hoằng Hóa, 
Tạp chí Các Khoa học về Trái Đất, 38 (1), 59-65

hiện tượng xói lở diễn ra mạnh có ảnh hưởng rất lớn tới an toàn các tuyến đề ngăn nước lũ. Bên cạnh bồi tụ phát triển ở cửa sông ven biển, hiện tượng xói lở cục bộ diễn ra ở một số nơi trên đoạn bờ biển cửa Lạch Trường, dài hàng chục kilomet. Xói lở xảy ra trong điều kiện, ngoài sự thiếu hụt bồi tích, hoạt động tích cực của đứt gãy có phương á kinh tuyến, chuyển động hạ lún hiện đại ở phía đông huyện Hậu Lộc. Tốc độ xói lở ở đoạn bờ biển phía bắc cửa Lạch Trường mạnh hơn đoạn phía nam. Xói lở bờ lấn sâu vào đất liền từ $250 \mathrm{~m}$ đến $300 \mathrm{~m}$ trong vòng 50 năm (1965-2015) với tốc độ trung bình $4-5 \mathrm{~m} /$ năm.

Cửa Hới là cửa chính thuộc hệ thống sông Mã, nằm giữa địa phận huyện Hoàng Hóa (bờ bắc) và thị xã Sầm Sơn (bờ nam). Trong hàng chục năm qua, cửa Hới biến động dưới tác động của thiên nhiên và hoạt động khai thác lãnh thổ của con người (Hoàng Ngọc Quang và nnk, 2008). Biến động lòng sông xảy ra chủ yếu ở các đoạn sông uốn khúc. Phía trong sông xói lở diễn ra mạnh mẽ hơn ngoài cửa sông. Bên trong cửa sông, xói lở bờ đạt $300 \mathrm{~m}$ với tốc độ $6 \mathrm{~m} / \mathrm{năm}$. Phía ngoài cửa sông ven bờ biển, xói lở bờ biển trung bình từ $150 \mathrm{~m}$ đến $250 \mathrm{~m}$ với tốc độ xói lở khoảng 3-5 m/năm. Khu vực ven biển phía bắc cửa Hới diễn ra hiện tượng xói lở - bồi tụ xen kẽ. Đáng chú ý là đoạn bờ xói lở dài hơn $6 \mathrm{~km}$ nằm trên địa phận các xã từ Hoằng Thanh tới Hoằng Tiến, hình thành vùng xói lở rộng trung bình $40 \mathrm{~m}$ và rộng nhất tới $125-130 \mathrm{~m}$; tốc độ xói lở bờ đạt $2-3 \mathrm{~m} /$ năm. Trên khu vực ven biển phía nam cửa Hới diễn ra hiện tượng xói lởbồi tụ xen kẽ trên đoạn bờ dài từ 1,2 đến $3 \mathrm{~km}$. Tốc độ xói lở bờ đạt 3-4 m/năm (bảng 1, hình 2).

\section{Kết luận}

Các quá trình địa mạo động lực (xói lở và bồi tụ) ở VCSVB sông Mã, tỉnh Thanh Hóa diễn ra rất phức tạp. Đây là khu vực nằm trong môi trường động, chịu ảnh hưởng của các yếu tố tự nhiên và hoạt động KT-XH của con người. Ngoài các yếu tố dòng chảy, sóng, hoạt động kinh tế của con người, chuyển động kiến tạo hiện đại phân dị đã làm phức tạp thêm quá trình địa mạo động lực của khu vực này.

Trên VCSVB, quá trình bồi tụ diễn ra từ thời kỳ Holocen sớm-giữa đến nay đã hình thành và phát triển địa hình đồng bằng tích tụ có nguồn gốc sông, sông-biển và biển. Đồng bằng tích tụ sôngbiển chủ yếu phân bố ở phía nam, tích tụ biển phân bố ở phía đông, đông bắc của VCSVB sông Mã.
Dải đồng bằng tích tụ sông Holocen muộn-hiện đại gồm các bãi bồi, thềm 1 chủ yếu phân bố ở dọc theo sông Mã và các chi lưu của nó.

Quá trình bồi tụ xảy ra ở Cửa Lèn và Cửa Hới, trong điều kiện chuyển động kiến tạo hạ lún và lượng bồi tích lớn. Hoạt động bồi tụ ở đây tạo nên các cung lồi hoặc mũi nhô ra phía biển. Tốc độ bồi tụ lớn, tạo bãi, bar tiến xa ra phía biển trung bình là 40-50 m/năm ở Cửa Lèn, 5-10 m/năm ở Cửa Hới.

Quá trình xói lở diễn ra khá mạnh trên đoạn bờ biển kéo dài từ phía bắc đến nam Cửa Lạch Trường, dài hàng chục kilomet, với tốc độ 5-6 $\mathrm{m} / \mathrm{năm}$; ở Cửa Hới với tốc độ 3-5 m/năm. Quá trình xói lở diễn ra trong điều kiện, ngoài sự thiếu hụt bồi tích, còn có hoạt động tích cực của đứt gãy hoạt động, chuyển động hạ lún hiện đại trên khu vực này.

\section{Tài liệu dẫn}

Nguyễn Văn Cư (chủ biên), 1999: Điều tra cơ bản tài nguyên môi trường nhằm khai thác hợp lí đất hoang hoá các bãi bồi ven biển cửa sông Việt Nam. Đề án điều tra cơ bản cấp nhà nước, Viện Địa lí, Hà Nội.

Nguyễn Văn Cư, Phạm Huy Tiến, 2003: Sạt lở bờ biển miền Trung Việt Nam. Nxb. KH\&KT Hà Nội, 200trg.

Phạm Văn Hùng, Vũ Thị Thu Hoài, 2009: Đặc điểm địa mạo động lực vùng cửa sông ven biển từ cửa $\mathrm{Ba}$ Lạt đến cửa Đáy. Tạp chí Các Khoa học về Trái đất, T.31, (3), Hà Nội.

Nguyễn Văn Hùng, 2002: Đặc điểm cơ bản của đứt gãy Tân kiến tạo khu vực Tây Bắc. Luận án Tiến sĩ, Viện Địa chất, Hà Nội.

Hoàng Ngọc Quang (chủ biên), 2008: Nghiên cứu quản lý tổng hợp tài nguyên và môi trường lưu vực sông Mã. Báo cáo đề tài cấp Bộ Tài nguyên và Môi trường, Hà Nội.

Phạm Quang Sơn, Nguyễn Tiến Công, Vũ Thị Thu Hoài, 2007: Diễn biến vùng ven biển các tỉnh Nam Định, Ninh Bình trước và sau khi có công trình thủy điện Hòa Bình qua phân tích thông tin viễn thám và GIS. Tạp chí Các Khoa học về Trái Đất. T.19, 3, tr.267-276.

Nguyễn Thế Thôn, 1994: Chuyển động tân kiến tạo và hiện đại của dải ven biển và ven bờ từ Móng Cái đến Cửa Hội. Tạp chí Địa Chất, Loạt A, số 223, tr.1-6.

Phạm Huy Tiến (chủ biên), 2004: Dự báo hiện tượng xói lở bồi tụ bờ biển cửa sông và các giải pháp phòng tránh. Báo cáo tổng kết đề tài $\mathrm{KHCN}$ cấp Nhà nước KC-09-05. Viện Địa lý, Viện KH\&CNVN, Hà Nội. 
Tạp chí Các Khoa học về Trái Đất, 38 (1), 59-65 